\title{
Is the Comet Assay a Sensitive Procedure for Detecting Genotoxicity?
}

\section{Satomi Kawaguchi, ${ }^{1}$ Takanori Nakamura, ${ }^{2}$ Ayumi Yamamoto, ${ }^{1}$ Gisho Honda, ${ }^{2}$ and Yu F. Sasaki ${ }^{1}$}

\author{
${ }^{1}$ Laboratory of Genotoxicity, Faculty of Chemical and Biological Engineering, Hachinohe National College of Technology, \\ Uwanotai 16-1, Hachinohe, Aomori 039-1192, Japan \\ ${ }^{2}$ Department of Pharmaceutical Health Care, Faculty of Pharmaceutical Sciences, Himeji Dokkyo University, Kamiohno 7-2-1, \\ Himeji, Hyogo 670-8524, Japan
}

Correspondence should be addressed to Yu F. Sasaki, yfsasakiaugsta@yahoo.co.jp

Received 30 May 2010; Revised 9 September 2010; Accepted 4 October 2010

Academic Editor: Shigenori Iwai

\begin{abstract}
Copyright ( 2010 Satomi Kawaguchi et al. This is an open access article distributed under the Creative Commons Attribution License, which permits unrestricted use, distribution, and reproduction in any medium, provided the original work is properly cited.
\end{abstract}

\begin{abstract}
Although the Comet assay, a procedure for quantitating DNA damage in mammalian cells, is considered sensitive, it has never been ascertained that its sensitivity is higher than the sensitivity of other genotoxicity assays in mammalian cells. To determine whether the power of the Comet assay to detect a low level of genotoxic potential is superior to those of other genotoxicity assays in mammalian cells, we compared the results of Comet assay with those of micronucleus test (MN test). WTK1 human lymphoblastoid cells were exposed to methyl nitrosourea (MNU), ethyl nitrosourea (ENU), methyl methanesulfonate (MMS), ethyl methanesulfonate (EMS), bleomycin (BLM), or UVC. In Comet assay, cells were exposed to each mutagen with (Comet assay/araC) and without (Comet assay) DNA repair inhibitors ( $\mathrm{araC}$ and hydroxyurea). Furthermore, acellular Comet assay (acellular assay) was performed to determine how single-strand breaks (SSBs) as the initial damage contributes to DNA migration and/or to micronucleus formation. The lowest genotoxic dose (LGD), which is defined as the lowest dose at which each mutagen causes a positive response on each genotoxicity assay, was used to compare the power of the Comet assay to detect a low level of genotoxic potential and that of MN test; that is, a low LGD indicates a high power. Results are summarized as follows: (1) for all mutagens studied, LGDs were MN test $\leqq$ Comet assay; (2) except for BLM, LGDs were Comet assay/araC $\leqq$ MN test; (3) except for UVC and MNU, LGDs were acellular assay $\leqq$ Comet assay/araC $\leqq \mathrm{MN}$ test $\leqq$ Comet assay. The following is suggested by the present findings: (1) LGD in the Comet assay is higher than that in MN test, which suggests that the power of the MN test to detect a low level of genotoxic potential is superior to that of the Comet assay; (2) for the studied mutagens, all assays were able to detect all mutagens correctly, which suggests that the sensitivity of the Comet assay and that of the MN test were exactly identical; (3) the power of the Comet assay to detect a low level of genotoxic potential can be elevated to a level higher than that of MN test by using DNA resynthesis inhibitors, such as araC and HU.
\end{abstract}

\section{Introduction}

Many methods have been used to identify genotoxic substances, including the detection of DNA damage, chromosome aberrations, and gene mutations both in vitro and in vivo. The Comet assay, which can detect single-strand breaks (SSBs) as initial damage and those developed from alkali-labile sites under alkaline condition $(\mathrm{pH}>12.6)$, is a rapid and sensitive procedure for detecting genotoxicity in mammalian cells $[1,2]$. When the sensitivity of a genotoxicity testing method is regarded as high, it means that it can detect wide variety of compounds with unknown genotoxic potential and that the assay can detect a low level of genotoxic potential by known genotoxic compounds. The former is very important in order to avoid pseudonegative results. In general, therefore, compounds with unknown genotoxic potential are assayed at a high dose, including maximum tolerated (subtoxic) dose. The genotoxic dose response curve for genotoxic compounds is thought to reach zero without having a no-response level at a low 
Journal of Nucleic Acids

dose. This statement forms the basis of the "nonthreshold concept" in the risk assessment, which describes the absence of a threshold in genotoxic potential. The "nonthreshold concept" for genotoxic compounds means that these agents could have an influence on humans even at very low-levels [3]. Therefore, it is important to detect low level genotoxicity.

Although the Comet assay is considered highly sensitive $[1,2]$, it has not been well ascertained whether its sensitivity to detect genotoxicity is higher than that of other procedures. Although the Comet assay is essentially a method of detecting single-strand breaks (SSBs), we have shown that a low level of SSB as the initial damage cannot be detected by the Comet assay because these SSBs disappear following a repair event and that SSBs as initial DNA damage can be well detected in the acellular Comet assay (acellular assay) [4]. The Comet assay can directly detect not only SSBs as initial DNA damage but also SSBs that develop from alkali-labile sites under alkaline condition $(\mathrm{pH}>12.6)$ and that formed during repair of base adducts or alkylated bases, which are not initial DNA damage [5]. The micronucleus test ( $\mathrm{MN}$ test) is a standard procedure that can detect structural chromosome aberrations derived from initial damage in the $\mathrm{S}$ phase and/or numerical chromosome aberrations due to aneugenic effects in the $\mathrm{M}$ phase $[6,7]$. Pfau et al. [8] conducted combined experiments with MLC5 cells including Comet assay and MN test and showed that the genotoxicity of heterocyclic amines was observed at concentrations that were 2000-fold lower on MN test than on Comet assay. However, Van Goethem et al. showed that the lowest genotoxic concentrations of pure cobalt powder, a cobalt-containing alloy, and cobalt-tungsten carbide were lower on Comet assay than on MN test [9]. Hartmann et al. [10] tested 36 pharmaceutical compounds with unknown genotoxic potential comparatively in the Comet assay and MN test using V79 Chinese hamster cells and reported that more compounds were positive in the MN test than in the Comet assay. Kawaguchi et al. [11] conducted combined experiments with TK6 and WTK1 cells including the Comet assay, chromosome aberration assay, and $T K$ mutation assay and showed that the genotoxicity of kojic acid was observed at $\geqq 2500 \mu \mathrm{g} / \mathrm{mL}$ on Comet assay and the chromosome aberration test and at $\geqq 1250 \mu \mathrm{g} / \mathrm{mL}$ on $T K$ mutation assay. However, the exposure conditions used in some of those studies differed among different assays (Pfau et al. [8] exposed cells for $30 \mathrm{~min}$ and $24 \mathrm{~h}$ in the Comet assay and MN test, resp.) and model mutagens with wellcharacterized action mechanisms were not used, making it difficult to systematically compare the sensitivities of those assays including the Comet assay. In our series of studies using well-known mutagens, we showed that SSBs as initial damage can be well detected by acellular assay but not by Comet assay under standard condition [4] and that the response of Comet assay to mutagens inducing DNA damage that can be repaired by the excision repair system tended to be affected by $p 53$ status [12]. Here, to discuss whether that the power of the Comet assay to detect a low level of genotoxic potential is superior to that of $\mathrm{MN}$ test, we conducted combined experiments with TK6 cells including (standard) Comet assay, acellular assay, and MN test under identical exposure conditions.

\section{Materials and Methods}

2.1. Chemicals. Methyl methanesulfonate (MMS) and ethyl methanesulfonate (EMS) were obtained from Sigma Chemicals Inc., St. Louis, MO (U.S.A.). Methyl nitrosourea (MNU) and ethyl nitrosourea (ENU) were purchased from Nacalai Tesque, Inc., Kyoto (Japan). They were dissolved in dimethyl sulfoxide (DMSO, Wako Pure Chemical Industries, Ltd., Osaka). Bleomycin (BLM, Wako Pure Chemical Industries, Ltd.) was dissolved in physiological saline. The DNA repair inhibitors hydroxyurea (HU) and cytosine-1$\beta$-D-arabinofuranoside (araC), purchased from Wako Pure Chemical Industries, Ltd., were dissolved in physiological saline. Regular (GP-42) and low melting point (LGT) agarose were obtained from Nacalai Tesque, Inc. and were diluted to $1 \%$ in physiological saline.

2.2. Cells. $\mathrm{TK}^{+/-}$heterozygote of the TK6 human lymphoblastoid cells exhibiting wild-type p53 (generously donated by Dr. Honma, National Institute of Health Sciences, Tokyo) were used. Cells were maintained in logarithmic growth using RPMI 1640 medium (Nissui Pharmaceutical Co., Ltd.) supplemented with $10 \%$ horse serum (SAFC Biosciences), $200 \mu \mathrm{g} / \mathrm{mL}$ sodium pyruvate, and $200 \mu \mathrm{g} / \mathrm{mL}$ streptomycin at $37^{\circ} \mathrm{C}$ under a $5 \% \mathrm{CO}_{2}$ atmosphere.

2.3. Cell Treatment with Mutagens. Cells were centrifuged and resuspended in a culture medium at a concentration of $5 \times 10^{5}$ cells $/ \mathrm{mL}$, and $1 \mathrm{~mL}$ of cell suspensions containing each chemical mutagen were incubated for $2 \mathrm{~h}$ in the presence (Comet assay/araC) or absence (Comet assay) of the DNA repair inhibitors araC $(1.8 \mathrm{mM})$ and $\mathrm{HU}(10 \mathrm{mM})$. (The two inhibitors were used at concentrations that did not induce significant reductions in cell viability [12].) On Comet assay and Comet assay/araC, exposed cells were sampled immediately after chemical treatment, and the percentage of viable cells was measured by the trypan blue exclusion test. Relative survival (survival under each concentration compared with that of an untreated control) was obtained. For UVC irradiation, $1 \mathrm{~mL}$ of cell suspension in saline $(5 \times$ $10^{5}$ cells $/ \mathrm{mL}$ ) in a $6-\mathrm{cm}$ dish was irradiated with a germicide lamp (National GL15, 15W, Matsushita Electric Industrial Co., Japan), as the UVC source from a distance of $15 \mathrm{~cm}$. Irradiated cells were incubated for $2 \mathrm{~h}$ in fresh medium with (Comet assay/araC) or without (Comet assay) DNA repair inhibitors (araC and $\mathrm{HU}$ ) and then sampled.

2.4. Comet Preparation. Treated cells were suspended in $1 \%$ agarose-LGT at $5 \times 10^{5}$ cells $/ 75 \mu \mathrm{L}$, and $75 \mu \mathrm{L}$ of cell suspension was immediately deposited on a fully frosted slide (Matsunami Glass Ind., Ltd., Osaka, Japan) which was coated with $1 \%$ agarose GP-42 and then covered with another slide glass. Although $0.5 \%$ LGT agarose is generally used, $1 \%$ LGT agarose (Nacalai Tesque, Inc.) was used in this study. In the case of LGT agarose obtained from Nacalai Tesque, Inc., $0.5 \%$ LGT is too soft to be used routinely in this assay. Although DNA migration tended to be lower in 1\% LGT than in $0.5 \%$ LGT, there was no qualitative difference in the responses of 
this assay in $0.5 \%$ and $1 \%$ (Figure 4 ), which is why $0.5 \%$ LGT agarose was used.

The slides were placed so as to allow the agarose to gel. The samples on the slides were then immediately exposed to a lysing solution ( $\mathrm{pH} \mathrm{10)}$ of $2.5 \mathrm{M} \mathrm{NaCl}, 100 \mathrm{mM} \mathrm{EDTA}$ disodium ( $\mathrm{Na}_{2} \mathrm{EDTA}$ ), $10 \mathrm{mM}$ Trizma, $1 \%$ sarkosyl, $10 \%$ DMSO, and $1 \%$ Triton X-100 and incubated at $4^{\circ} \mathrm{C}$ for $1 \mathrm{~h}$. The slides were then placed on a horizontal gel electrophoresis platform and covered with $\mathrm{pH}>13$ alkaline solution composed of $300 \mathrm{mM} \mathrm{NaOH}$ and $1 \mathrm{mM} \mathrm{Na}_{2}$ EDTA. The slides were left in solution at $0^{\circ} \mathrm{C}$ for $20 \mathrm{~min}$ to allow unwinding of the DNA and expression of alkali-labile sites to occur. The power supply was set at $1 \mathrm{~V} / \mathrm{cm}$ and $250 \mathrm{~mA}$. The DNA was subjected to electrophoresis at $0^{\circ} \mathrm{C}$ for $20 \mathrm{~min}$, and the slides were rinsed with $400 \mathrm{mM}$ Trizma ( $\mathrm{pH}$ 7.5) to neutralize the excess alkalinity. Each slide was stained with $50 \mu \mathrm{L}$ of $20 \mu \mathrm{g} / \mathrm{mL}$ ethidium bromide (Wako Pure Chemical Industries, Ltd.) and covered with a coverslip. One hundred cells on two slides per dose (two slides were prepared for each dose) were examined and photographed (black and white ASA 400 Fuji film) at 200x magnification using a fluorescence microscope (Olympus) equipped with G filter. The whole length of the Comet ("migration") was measured.

The measures of DNA migration include many parameters [13]: \% of damaged cells (i.e., cells with tails), damaged categories (classified into various types or intensities based on shape), length of DNA migration (total or tail), and tail moment (e.g., amount of tail DNA x tail length). Although the use of \% tail DNA is recommended [13], we used the whole length of the Comet as a unique parameter. Although the Comet image length is likely to be quantitatively inferior to $\%$ tail DNA, its qualitative power to differentiate positive and negative responses is not unsuitable and no parameters are unacceptable [13]. In this study, the responses on Comet assay were not analyzed quantitatively. LGDs for two versions of the Comet assay and MN test were obtained from qualitative analysis of the results (differentiation between positive and negative responses at each dose). Therefore, use of the whole length of the Comet as a unique parameter is not considered to have affected the results of this study.

The effect of chemical treatment on migration was analyzed using ANOVA and Dunnett test. The lowest genotoxic dose (LGD) was defined as the lowest dose where DNA migration increased significantly. In this study, LGD was used to compare the power of each assay to detect a low level of genotoxic potential of each mutagen; that is, low LGD shows high power.

2.5. Acellular Comet Assay (Acellular Assay). Slides for the Comet assay from untreated TK6 cells were prepared as outlined above and the slides were lysed immediately in a lysing solution at $4^{\circ} \mathrm{C}$ for one hour as described above. Lysed slides were neutralized in $400 \mathrm{mM}$ Tris $\mathrm{HCl}$ buffer $(\mathrm{pH} 7.5)$ for $15 \mathrm{~min}$ and exposed to RPMI 1640 medium with $10 \%$ horse serum containing different concentrations of the test agents for $2 \mathrm{~h}$ at $37^{\circ} \mathrm{C}$ in the dark. After the treatment period, the slides were rinsed by immersion in cold distilled water, and then the slides were electrophoresed at $\mathrm{pH}>13$ and $0^{\circ} \mathrm{C}$ for 20 min after unwinding of the DNA at $\mathrm{pH}>13$ for $20 \mathrm{~min}$. The power supply was set at $1 \mathrm{~V} / \mathrm{cm}$ and $250 \mathrm{~mA}$. In the Comet assay, although SSBs could be differentiated from alkali-labile lesions derived from base lesions; SSBs could be detected by electrophoresis at $\mathrm{pH} 12.1$ and both SSBs and alkali-labile lesions by electrophoresis at $\mathrm{pH}>13$ [14]. DNA damage detected under the acellular condition at both $\mathrm{pH}$ 12 and $\mathrm{pH}>13$ were shown to be SSBs but not alkalilabile lesions, and there were no differences in the responses of the acellular assay at $\mathrm{pH}>13$ from those at $\mathrm{pH} 12$ [15], which is why electrophoresis was conducted at $\mathrm{pH}>13$. For UVC irradiation, neutralized slides were irradiated by a germicide lamp (National GL15, 15W, Matsushita Electric Industrial Co., Japan) from a distance of $15 \mathrm{~cm}$. Irradiated slides were incubated for $2 \mathrm{~h}$ in $400 \mathrm{mM}$ Tris $\mathrm{HCl}$ buffer immediately after UVC-irradiation, and then the slides were electrophoresed at $\mathrm{pH}>13$ as described above.

2.6. Micronucleus Test (MN Test). Cells were exposed to each mutagen as described above. At the end of a treatment period, the cells were washed with Hanks' BSS and cultured for $24 \mathrm{~h}$ in medium containing cytochalasin B at $3 \mu \mathrm{g} / \mathrm{mL}$, and then cells were sampled. For UVC irradiation, $1 \mathrm{~mL}$ of cell suspension in saline $\left(1 \times 10^{6}\right.$ cells $\left./ \mathrm{mL}\right)$ in $6-\mathrm{cm}$ dish was irradiated by a germicide lamp (National GL15, 15W, Matsushita Electric Industrial Co., Japan) as the UVC source from a distance of $15 \mathrm{~cm}$. Irradiated cells were incubated for $24 \mathrm{~h}$ in medium containing cytochalasin B at $3 \mu \mathrm{g} / \mathrm{mL}$, and then cells were sampled. The collected cells were suspended in $0.075 \mathrm{M} \mathrm{KCl}$ hypotonic solution for $15 \mathrm{~min}$, the cell suspension was concentrated to a volume of $1 \mathrm{~mL}$, mixed with $1 \mathrm{~mL}$ of $10 \%$ neutral buffered formalin solution and then concentrated to a volume of $100 \mu \mathrm{L}$. The cell suspension was further mixed with $100 \mu \mathrm{L}$ of $0.05 \mathrm{w} / \mathrm{v} \%$ aqueous solution of acridine orange, and then $50 \mu \mathrm{L}$ of cell suspension was placed on a slide glass and mounted with $24 \times$ $48 \mathrm{~mm}$ cover slips. Binuclei cells with micronuclei (MNBNC) per 2000 binuclei cells (BNC) and BNC per 2000 cells were scored with the aid of fluorescence microscope (Olympus at 600x magnification) equipped with a B filter. The prevalence of MNBNC was analyzed statistically by $\chi^{2}$ test. The lowest genotoxic dose (LGD) was defined as the lowest dose at which MNBNC increased significantly.

\section{Results}

Results of the Comet assay and Comet assay/araC are shown in Figure 1. Results of acellular assay and MN test are shown in Figures 2 and 3, respectively. LGDs are summarized in Table 1.

Both in Comet assay and Comet assay/araC, BLM, alkylating agents (MMS, EMS, MNU, and ENU), and UVC increased DNA migration significantly. In general, detection of DNA migration was greater on Comet assay/araC than on Comet assay. Both in the Comet assay and Comet assay/araC, relative survivals were $>70 \%$ in the dose range of studied mutagens (data not shown). On acellular assay, BLM and alkylating agents, but not UVC, increased DNA migration 


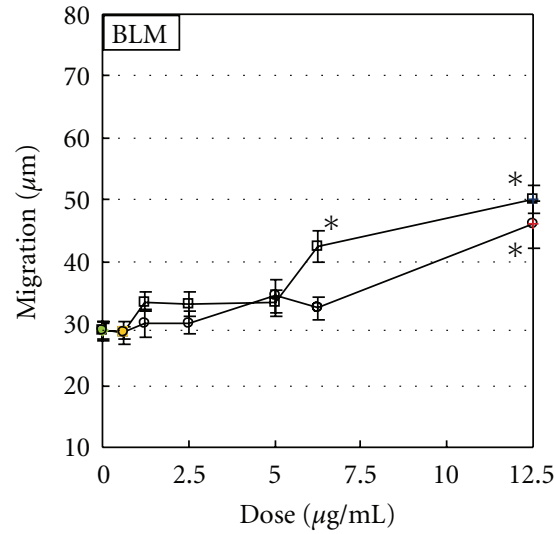

(a)

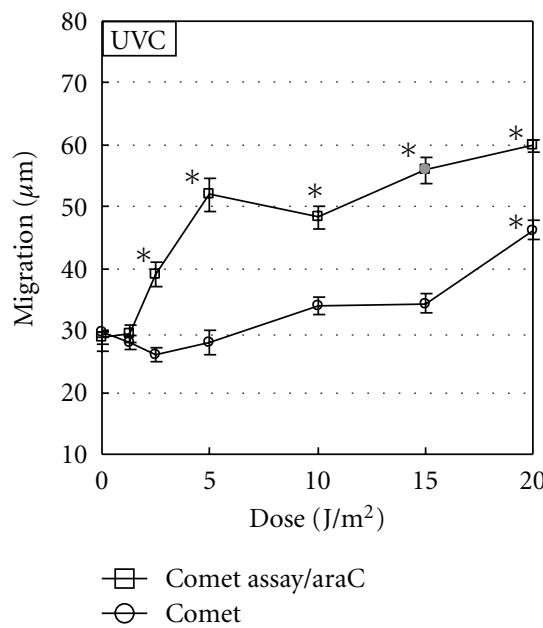

(d)

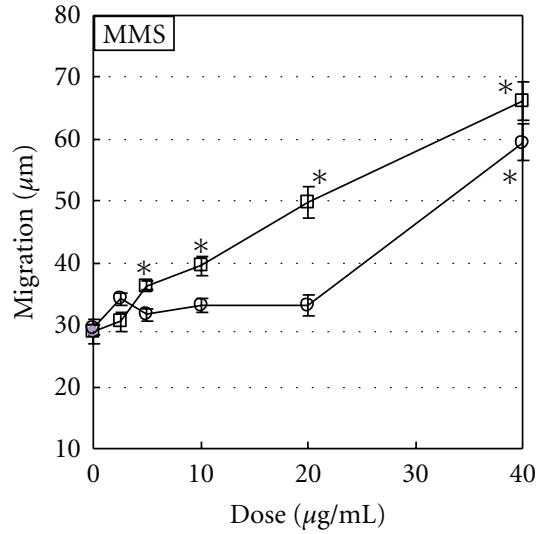

(b)

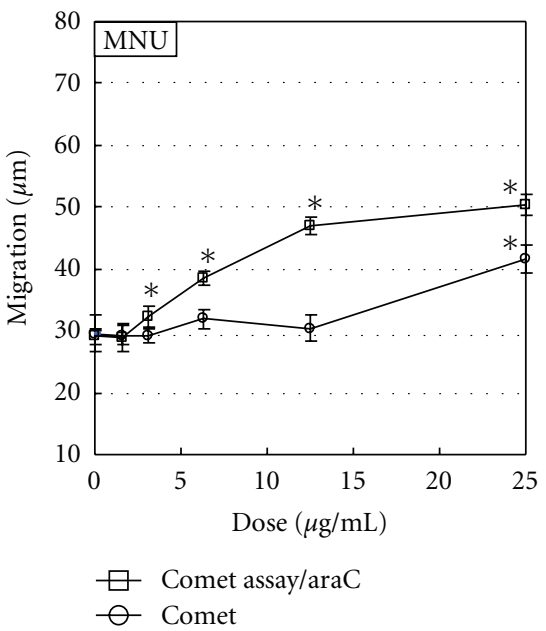

(e)

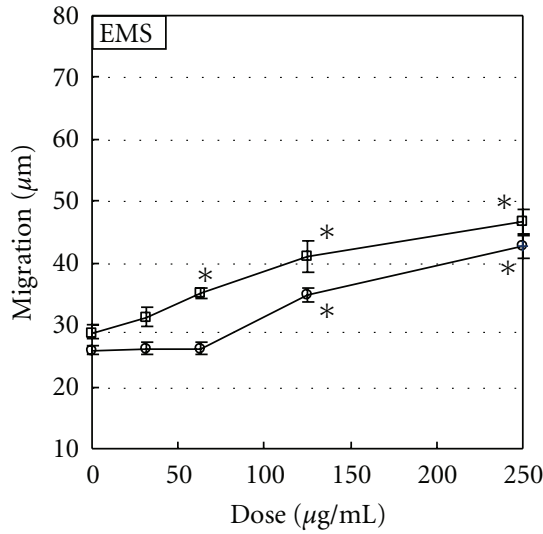

(c)

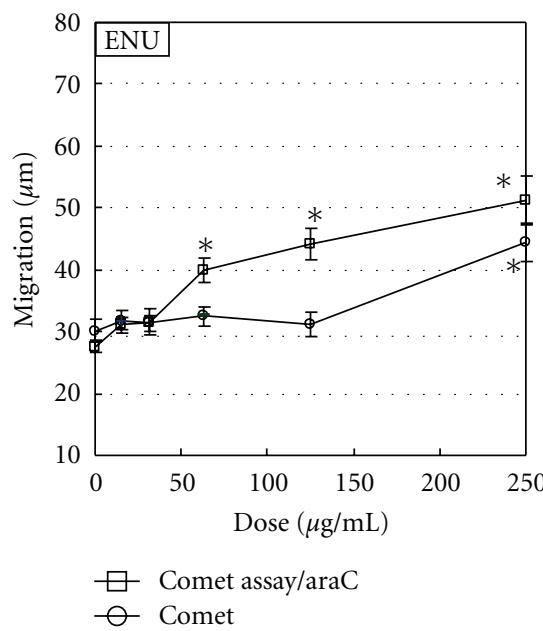

(f)

FIgURE 1: Comet assay and Comet assay/araC in TK6 cells. Slides for Comet assay were prepared immediately after the exposure to chemical mutagens for $2 \mathrm{~h}$ with or without araC/HU, or $2 \mathrm{~h}$ culture with or without araC/HU after UVC irradiation. Electrophoresis was conducted at $\mathrm{pH}>13$. Reproducibility was ascertained by three independent experiments, and representative data are shown. The error bars indicate standard errors of the mean. ${ }^{*}$ Significant difference from untreated control: $P<.05$.

TABLE 1: LGDs for Comet assay, Comet assay/araC, acellular assay, and MN test using TK6 cells.

\begin{tabular}{lccccc}
\hline Mutagen & Comet assay & Comet assay/araC & acellular assay & MN test & $\begin{array}{c}\text { Ratio of LGD } \\
\text { (Comet assay: MN test) }\end{array}$ \\
\hline UVC & 20 & 2.5 & - & 15 & 1.3 \\
MNU & 25 & 3.125 & 6.25 & 3.5 & 2 \\
ENU & 250 & 62.5 & 1.3 & 125 & 2 \\
MMS & 40 & 20 & 62.5 & 20 & 2 \\
EMS & 125 & 62.5 & 0.0625 & 125 & 1 \\
BLM & 12.5 & 6.25 & & 5 & 2.5 \\
\hline
\end{tabular}

significantly. On MN test, BLM, alkylating agents, and UVC increased MNBNC significantly.

For BLM, LGDs were $12.5 \mu \mathrm{g} / \mathrm{mL}, 6.25 \mu \mathrm{g} / \mathrm{mL}, 0.0625 \mu \mathrm{g} /$ $\mathrm{mL}$, and $5 \mu \mathrm{g} / \mathrm{mL}$ in the Comet assay, Comet assay/araC, cellular assay, and MN test, respectively; that is, LGDs were acellular assay $<\mathrm{MN}$ test $<$ Comet assay/araC $<$ Comet assay. For MMS, LGDs were $40 \mu \mathrm{g} / \mathrm{mL}, 20 \mu \mathrm{g} / \mathrm{mL}, 10 \mu \mathrm{g} / \mathrm{mL}$, and $20 \mu \mathrm{g} / \mathrm{mL}$ on Comet assay, Comet assay/araC, acellular assay, and $\mathrm{MN}$ test, respectively; that is, acellular assay < Comet assay/araC $=\mathrm{MN}$ test $<$ Comet assay. For EMS, LGDs were $125 \mu \mathrm{g} / \mathrm{mL}, 62.5 \mu \mathrm{g} / \mathrm{mL}, 62.5 \mu \mathrm{g} / \mathrm{mL}$, and $125 \mu \mathrm{g} / \mathrm{mL}$ on Comet assay, Comet assay/araC, acellular assay, and $\mathrm{MN}$ test, respectively; that is, acellular assay = Comet assay/araC $<\mathrm{MN}$ test $=$ Comet assay. For MNU, LGDs 


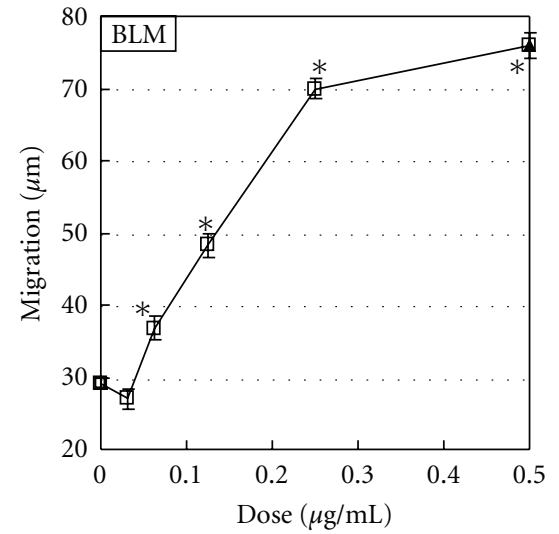

(a)

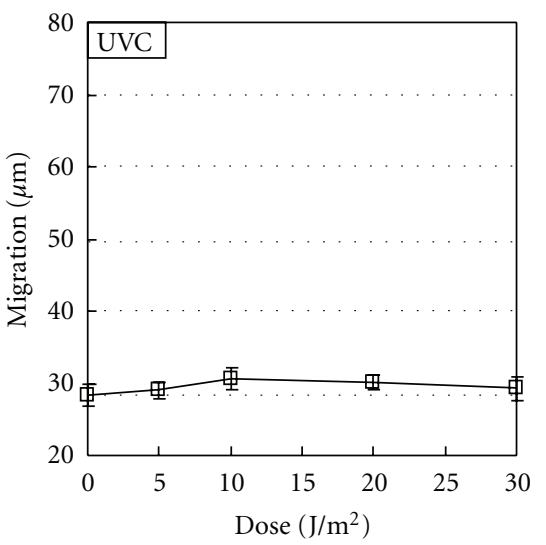

(d)

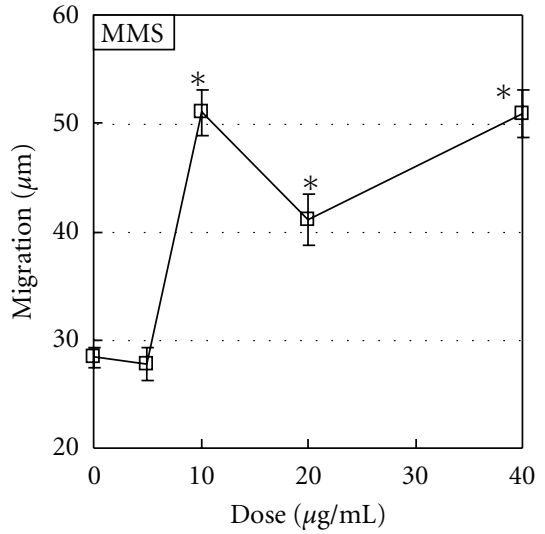

(b)

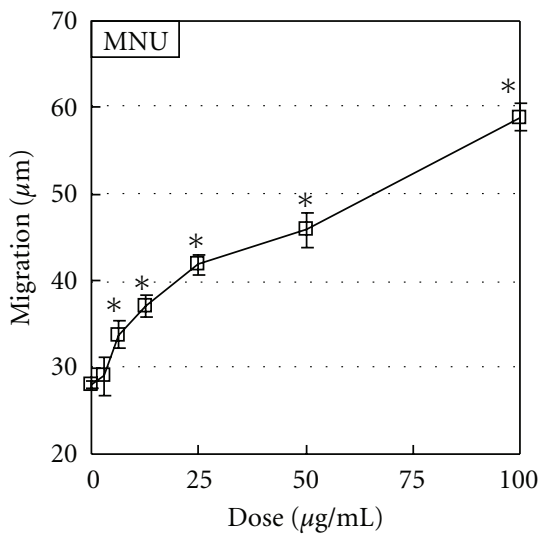

(e)

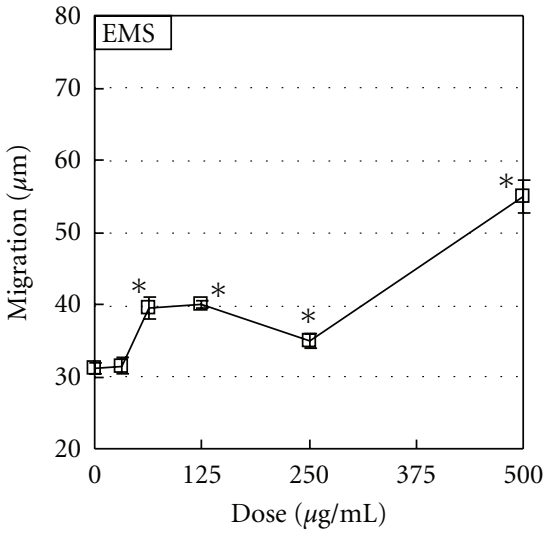

(c)

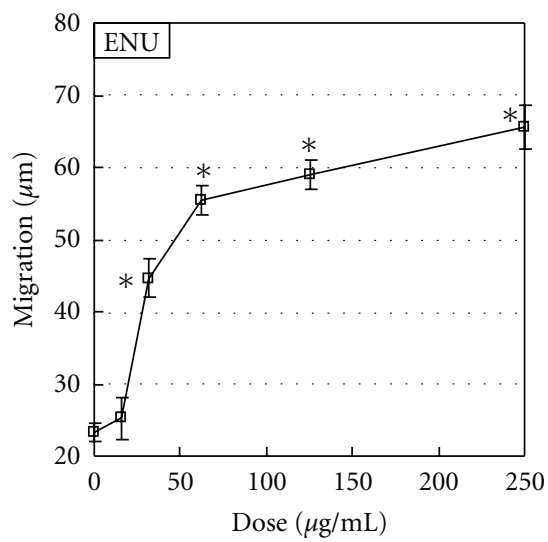

(f)

FIGURE 2: Acellular assay in TK6 cells. Slides for Comet assay were exposed to each chemical mutagen for $2 \mathrm{~h}$ or irradiated with UVC, and then electrophoresis was conducted at $\mathrm{pH}>13$ immediately after exposure to the chemical mutagen or $2 \mathrm{~h}$ after UVC irradiation. Reproducibility was ascertained by three independent experiments and representative data are shown. The error bars indicate standard errors of the mean.

${ }^{*}$ Significant difference from untreated control: $P<.05$.

were $25 \mu \mathrm{g} / \mathrm{mL}, 3.125 \mu \mathrm{g} / \mathrm{mL}, 6.25 \mu \mathrm{g} / \mathrm{mL}$, and $12.5 \mu \mathrm{g} / \mathrm{mL}$ on Comet assay, Comet assay/araC, acellular assay, and MN test, respectively; that is, Comet assay/araC $<$ acellular assay $<$ MN test < Comet assay. For ENU, LGDs were $250 \mu \mathrm{g} / \mathrm{mL}$, $62.5 \mu \mathrm{g} / \mathrm{mL}, 31.3 \mu \mathrm{g} / \mathrm{mL}$, and $125 \mu \mathrm{g} / \mathrm{mL}$ on Comet assay, Comet assay/araC, acellular assay, and MN test, respectively; that is, acellular assay $<$ Comet assay/araC $<$ MN test $<$ Comet assay. For UVC, LGDs were $20 \mathrm{~J} / \mathrm{m}^{2}, 2.5 \mathrm{~J} / \mathrm{m}^{2}$, and $15 \mu \mathrm{g} / \mathrm{mL}$ on Comet assay, Comet assay/araC, and MN test, respectively; that is, Comet assay/araC $<\mathrm{MN}$ test $<$ Comet assay.

\section{Discussion}

The present results are summarized as follows: (1) for all mutagens studied, LGDs were MN test $\leqq$ comet assay; (2) except for BLM, LGDs were Comet assay/araC $\leqq$ MN test; (3) except for UVC and MNU, LGDs were acellular assay $\leqq$ Comet assay/araC $\leqq \mathrm{MN}$ test $\leqq$ Comet assay. Therefore, despite the belief in the high sensitivity of Comet assay, its power in detecting a low level of genotoxicity was lower than that of MN test. Although the development of initial damage into alkali-labile sites following repair events is an important factor supporting the sensitivity of Comet assay, it is easily assumed that DNA resynthesis and rejoining events following SSB formation reduce the sensitivity of Comet assay in detecting DNA damage such as alkylated bases and bulky base adducts. In this study, we used two methods of canceling the effects of DNA resynthesis and/or rejoining events. One is acellular assay [16] and the other is the use of DNA repair inhibitors (araC and HU) [5, 17]. Acellular assay is a modified version of Comet assay, in which slides with gels prepared from untreated cells are exposed after lysis to test agents and then processed according to the standard protocol of the Comet assay. In the acellular assay, since lysed cells are exposed to test compounds, there are no biological events acting on the formation and/or disappearance of SSBs $[4,16]$. In our previous study, where positive responses on Comet and acellular assays were detected at $\mathrm{pH} 12$ and $>13$, there were no apparent $\mathrm{pH}$ effects on acellular assay, suggesting that SSBs as initial DNA damage are detected on acellular assay at $\mathrm{pH} 12$ and $\mathrm{pH}>13$ [15]. 


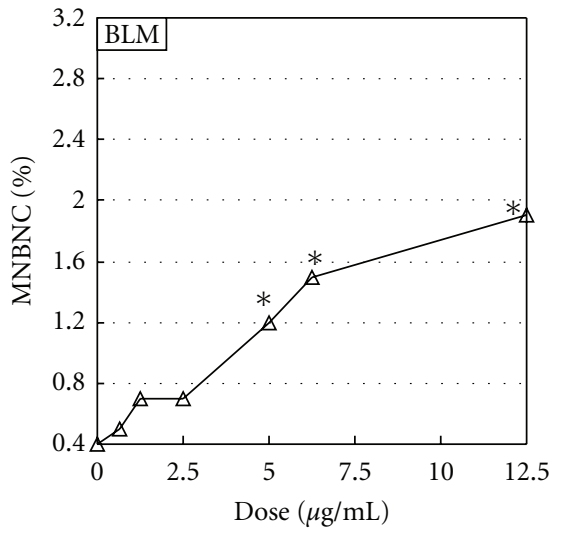

(a)

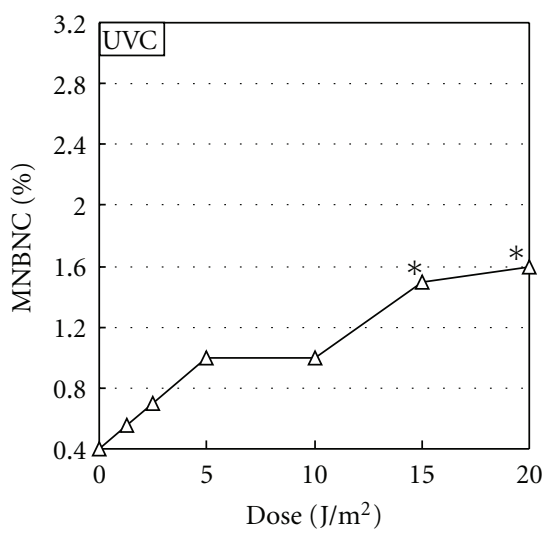

(d)

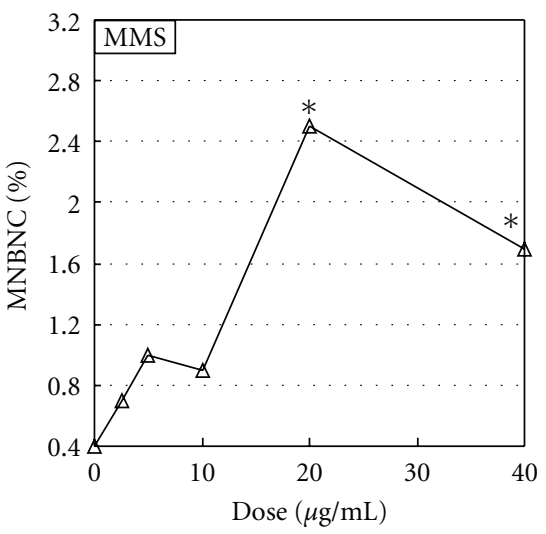

(b)

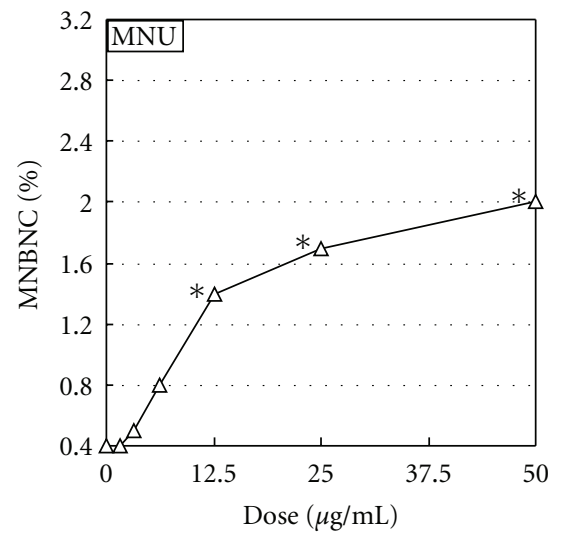

(e)

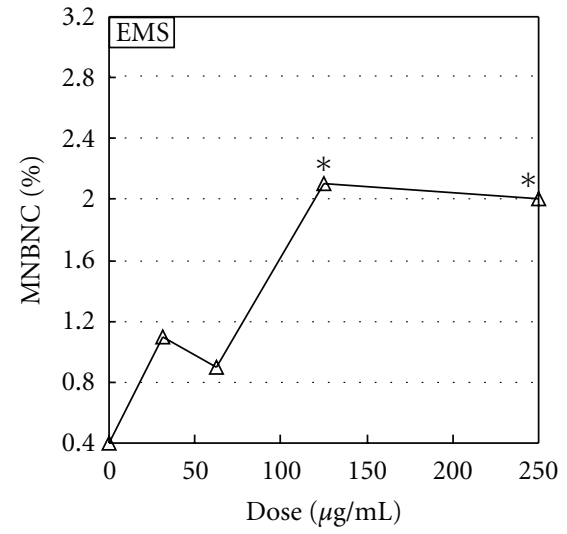

(c)

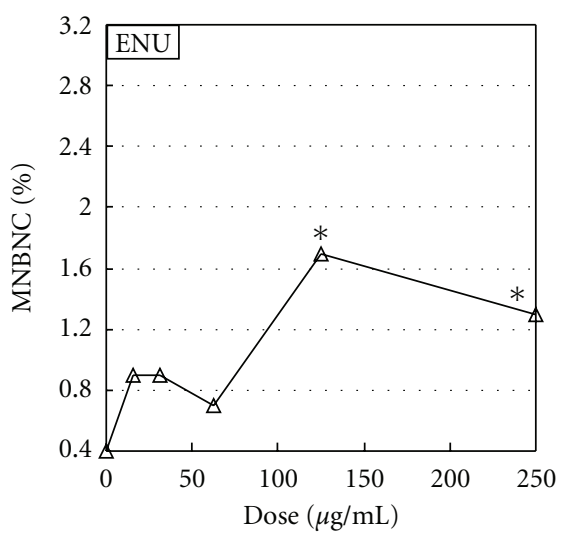

(f)

FIGURE 3: MN test in TK6 cells. TK6 cells were exposed to each chemical mutagen for $2 \mathrm{~h}$ or irradiated with UVC and were incubated for $24 \mathrm{~h}$ with cytochalasin B, and then slides for MN test were prepared. Reproducibility was ascertained by three independent experiments and representative data are shown. ${ }^{*}$ Significant difference from untreated control: $P<.05$.

When SSBs as initial DNA lesions are not rejoined, they would be responsible for DNA migration on Comet assay. For SSB-inducers such as BLM [18]; therefore, migration would be observed on acellular assay, while rejoining of SSBs before the preparation of the Comet assay would reduce positive response on Comet assay. If the level of SSBs as initial DNA damage is high enough to persist until the preparation of the Comet assay, migration would be observed in Comet assay. While BLM led to positive responses at $\geqq 0.0625 \mu \mathrm{g} / \mathrm{mL}$ on acellular assay, it led to negative responses at $\leqq 1.25 \mu \mathrm{g} / \mathrm{mL}$ on Comet assay. This discrepancy would be explained as follows. Although rejoining of BLM-induced SSBs before the preparation of the Comet assay reduces positive responses on Comet assay, rejoining of BLM-induced SSBs does not occur on acellular assay where none of the cellular functions remain active. The induction of SSBs by BLM at $\leqq 1.25 \mu \mathrm{g} / \mathrm{mL}$ would be too low to persist until the preparation of the Comet assay, which would be responsible for the negative and positive responses at $\leqq 1.25 \mu \mathrm{g} / \mathrm{mL}$ on Comet and acellular assays, respectively. The Comet assay detects SSBs as initial damage and SSBs formed through repairing process of initial damage other than SSBs $[1,2,4]$, while MN test detects structural chromosome aberrations that are derived from primary damage in the $\mathrm{S}$ phase and/or numerical chromosome aberrations due to aneugenic effects in the $\mathrm{M}$ phase $[6,7]$. Therefore, even if the SSB-induction level by BLM is too low to persist until the preparation of the Comet assay, SSBs that can persist until the start of the $S$ phase could form micronuclei, which could explain why LGDs are detected on the order of MN test $\leqq$ Comet assay.

Comet assay detects SSBs produced as initial damage as well as those generated during the repair of initial damage such as alkylated bases, bulky base adducts, and pyrimidine dimers $[1,2]$. Therefore, in the case of mutagens forming DNA adduct, the sensitivity of the Comet assay is supported by the conversion efficiency of initial damage into alkali-labile sites through the repair processes $[1,2]$. Pyrimidine dimers, which are well known to be induced by UVC, are removed by the nucleotide excision repair, which involves incision of the DNA strand, excision of the damaged nucleotide, gap filling by DNA resynthesis, and rejoining by ligation. As shown by the negative responses on acellular assay, it is considered that UVC does not induce SSBs as initial damage [4]. As shown by the positive responses 


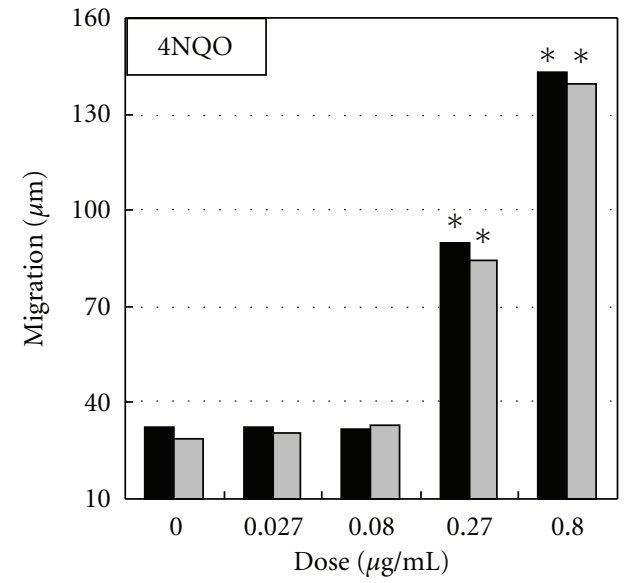

(a)

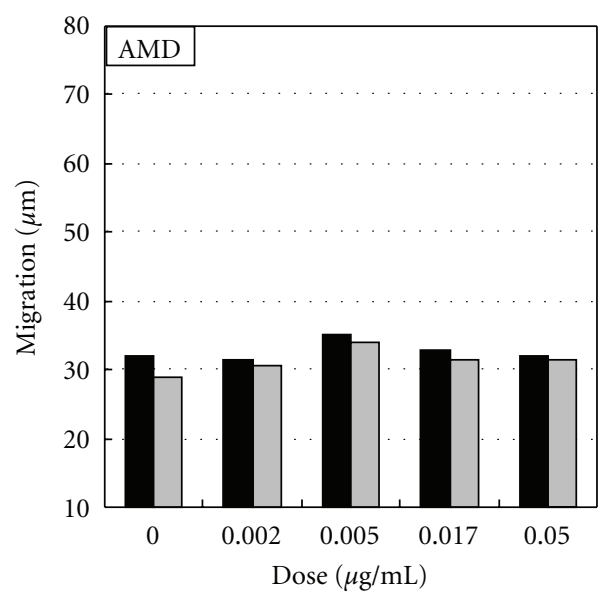

$0.5 \%$ LGT

$1 \%$ LGT

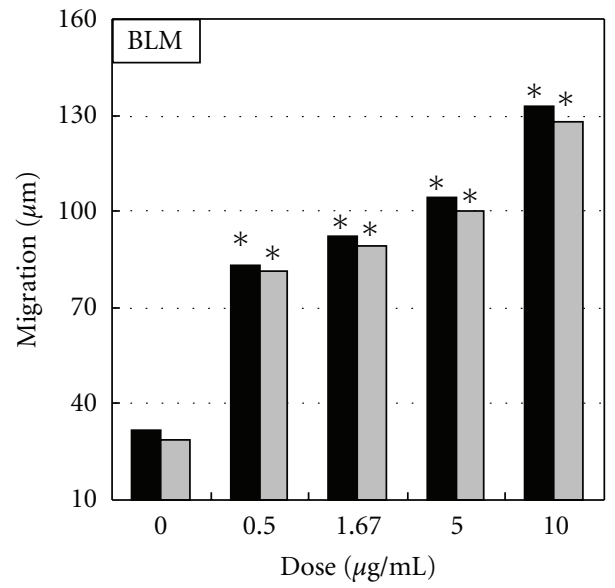

(b)

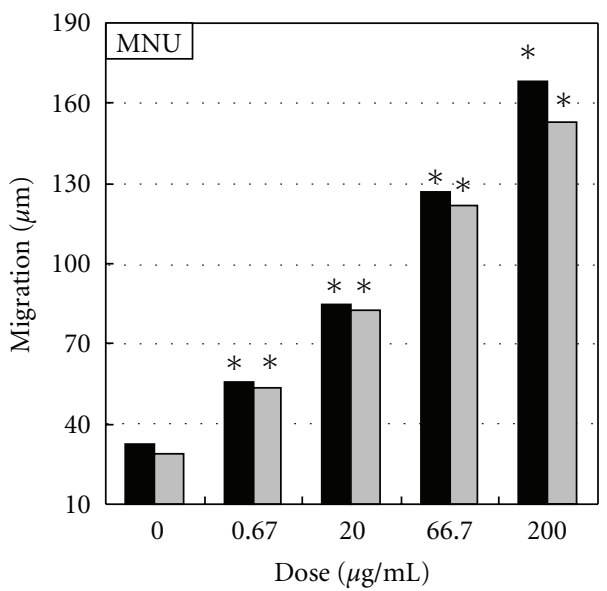

$0.5 \%$ LGT

$1 \%$ LGT

(c)

(d)

FIGURE 4: Comet assay in 0.5\% LGT and 1\% LGT. Chinese hamster CHO cells were exposed to each chemical mutagen for $1 \mathrm{~h}$, and then slides for Comet assay were prepared immediately after the exposure. Electrophoresis was conducted at pH > 13. 4NQO, 4-nitroquinoline-1-oxide; AMD, actinomycin D * Significant difference from untreated control: $P<.05$.

on acellular assay; however, it is considered that not only alkylated bases as initial damage but also SSBs as initial damage are induced by alkylating agents [4]. (SSBs as initial damage would not contribute markedly to positive responses on Comet assay [4].) SSBs that are formed during the process of repairing pyrimidine dimers and alkylated bases are responsible for the DNA migration observed on Comet assay [4]. SSB-rejoining, which reduces DNA migration, can be canceled by incubation with DNA synthesis inhibitors such as HU and araC, which block DNA resynthesis [5, 17]. LGDs of UVC and alkylating agents were MN test < Comet assay, suggesting that SSBs formed from pyrimidine dimers and alkylated bases that do not persist until the preparation of the Comet assay can form micronuclei. However, LGDs of UVC and alkylating agents were detected in the order of Comet assay/araC $<\mathrm{MN}$ test, suggesting that not all unrejoined SSBs form micronuclei and that the inhibition of the rejoining step during excision repair can elevate the power of the Comet assay to detect a low level of genotoxic potential to a level higher than that of $\mathrm{MN}$ test.

LGDs of BLM and studied mutagens except for BLM were 2.5 -fold and $\leqq 2$-fold higher on Comet assay than on MN test, respectively, which would suggest that the power of the Comet assay to detect a low level of genotoxic potential tended to be lower than that on $\mathrm{MN}$ test for mutagens that easily produce SSBs as the initial damage. This suggests that SSBs as initial damage might make a greater contribution to micronucleus formation than to DNA migration, considering our previous discussion that SSBs as the initial damage would not contribute markedly to positive responses on Comet assay [4]. Furthermore, it is considered that the second step of repair events includes gap filling by DNA resynthesis followed by ligation, which reduces the sensitivity on Comet assay to a level below that of 
MN test, though the progression of initial damage to alkalilabile sites during the repair process is an important factor contributing to the sensitivity on Comet assay.

In conclusion, the power of Comet assay to detect a low level of genotoxicity is lower than that of MN test, which concurs with the results reported by Pfau et al. [8]. For the studied mutagens, all assays (except for acellular assay for UVC) were able to detect all mutagens correctly, suggesting that the sensitivities of Comet assay and MN test were exactly identical. For the studied mutagens; however, LGDs on Comet assay were higher than those on MN test, suggesting that the power of $\mathrm{MN}$ test to detect low level of genotoxic potential is superior to that of Comet assay. Higher LGDs on MN test would depend on the selection of different spectra of damage by the Comet assay and MN test; that is, the formation of SSBs during repairing process is an important factor leading to positive responses on Comet assay and whether cells with unrepaired DNA damage can enter the $S$ phase to form structural chromosome aberrations would be an important factor leading to positive responses on MN test. Furthermore, whether LGDs on Comet assay are lower or higher than those on MN test would depend on which compounds are examined. Despite the lower power of the Comet assay to detect a low level of genotoxic potential, one of the most important advantages of the Comet assay is that DNA damage can be measured in any cell type [19], while the MN test is limited to cells having mitotic activity. Furthermore, the power of Comet assay to detect a low level of genotoxicity can be elevated to a level higher than that of $\mathrm{MN}$ test by using DNA resynthesis inhibitors, such as araC and $\mathrm{HU}$.

\section{References}

[1] N. P. Singh, M. T. McCoy, R. R. Tice, and E. L. Schneider, "A simple technique for quantitation of low levels of DNA damage in individual cells," Experimental Cell Research, vol. 175, no. 1, pp. 184-191, 1988.

[2] D. W. Fairbairn, P. L. Olive, and K. L. O’Neill, “The Comet assay: a comprehensive review," Mutation Research, vol. 339, no. 1, pp. 37-59, 1995.

[3] S. Fukushima, A. Kakehshi, M. Wei, and H. Wanibuchi, "Existence of a threshold for genotoxic carcinogens: evidence from mechanism-based carcinogenicity studies," Genes and Environment, vol. 32, pp. 33-36, 2009.

[4] S. Kawaguchi, T. Nakamura, G. Honda, N. Yokohama, and Y. F. Sasaki, "Detection of DNA single strand breaks induced by chemical mutagens using the acellular Comet assay," Genes and Environment, vol. 30, pp. 77-88, 2008.

[5] A. R. Collins, "The Comet assay for DNA damage and repair: principles, applications, and limitations," Molecular Biotechnology, vol. 26, no. 3, pp. 249-261, 2004.

[6] G. Obe, P. Pfeiffer, J. R. K. Savage et al., "Chromosomal aberrations: formation, identification and distribution," Mutation Research, vol. 504, no. 1-2, pp. 17-36, 2002.

[7] M. Fenech and A. A. Morley, "Measurement of micronuclei in lymphocytes," Mutation Research, vol. 147, no. 1-2, pp. 29-36, 1985.

[8] W. Pfau, F. L. Martin, K. J. Cole et al., "Heterocyclic aromatic amines induce DNA strand breaks and cell transformation," Carcinogenesis, vol. 20, no. 4, pp. 545-551, 1999.
[9] F. Van Goethem, D. Lison, and M. Kirsch-Volders, "Comparative evaluation of the in vitro micronucleus test and the alkaline single cell gel electrophoresis assay for the detection of DNA damaging agents: genotoxic effects of cobalt powder, tungsten carbide and cobalt-tungsten carbide," Mutation Research - Genetic Toxicology and Environmental Mutagenesis, vol. 392, no. 1-2, pp. 31-43, 1997.

[10] A. Hartmann, A. Elhajouji, E. Kiskinis et al., "Use of the alkaline Comet assay for industrial genotoxicity screening: comparative investigation with the micronucleus test," Food and Chemical Toxicology, vol. 39, no. 8, pp. 843-858, 2001.

[11] S. Kawaguchi, T. Nakamura, G. Honda, and Y. F. Sasaki, "Evaluation of in vitro genotoxic potential of kojic acid in human lymphoblastoid cells," Genes and Environment, vol. 29, pp. 153-158, 2007.

[12] T. Nakamura, A. Yamamoto, G. Honda, S. Kawaguchi, N. Yokohama, and Y. F. Sasaki, "Does p53 status affect the sensitivity of the Comet assay?" Genes and Environment, vol. 32, pp. 14-20, 2010.

[13] R. R. Tice, E. Agurell, D. Anderson et al., "Single cell gel/Comet assay: guidelines for in vitro and in vivo genetic toxicology testing," Environmental and Molecular Mutagenesis, vol. 35, no. 3, pp. 206-221, 2000.

[14] Y. Miyamae, K. Iwasaki, N. Kinae et al., "Detection of DNA lesions induced by chemical mutagens using the single-cell gel electrophoresis (Comet) assay. 2. Relationship between DNA migration and alkaline condition," Mutation Research Genetic Toxicology and Environmental Mutagenesis, vol. 393, no. 1-2, pp. 107-113, 1997.

[15] S. Kawaguchi, T. Nakamura, G. Honda, N. Yokohama, and Y. F. Sasaki, "Detection of DNA single strand breaks induced bychemical mutagens using the acellular Comet assay," Genes and Environment, vol. 30, pp. 77-88, 2008.

[16] T. Kasamatsu, K. Kohda, and Y. Kawazoe, "Comparison of chemically induced DNA breakage in cellular and subcellular systems using the Comet assay," Mutation Research, vol. 369, no. 1, pp. 1-6, 1996.

[17] E. Rojas, M. C. Lopez, and M. Valverde, "Single cell gel electrophoresis assay: methodology and applications," Journal of Chromatography B: Biomedical Sciences and Applications, vol. 722, no. 1-2, pp. 225-254, 1999.

[18] B. K. Vig and R. Lewis, "Genetic toxicology of bleomycin," Mutation Research, vol. 49, pp. 189-238, 1978.

[19] Y. F. Sasaki, K. Sekihashi, F. Izumiyama et al., "The Comet assay with multiple mouse organs: comparison of Comet assay results and carcinogenicity with 208 chemicals selected from the IARC monographs and U.S. NTP carcinogenicity database," Critical Reviews in Toxicology, vol. 30, no. 6, pp. 629-799, 2000. 

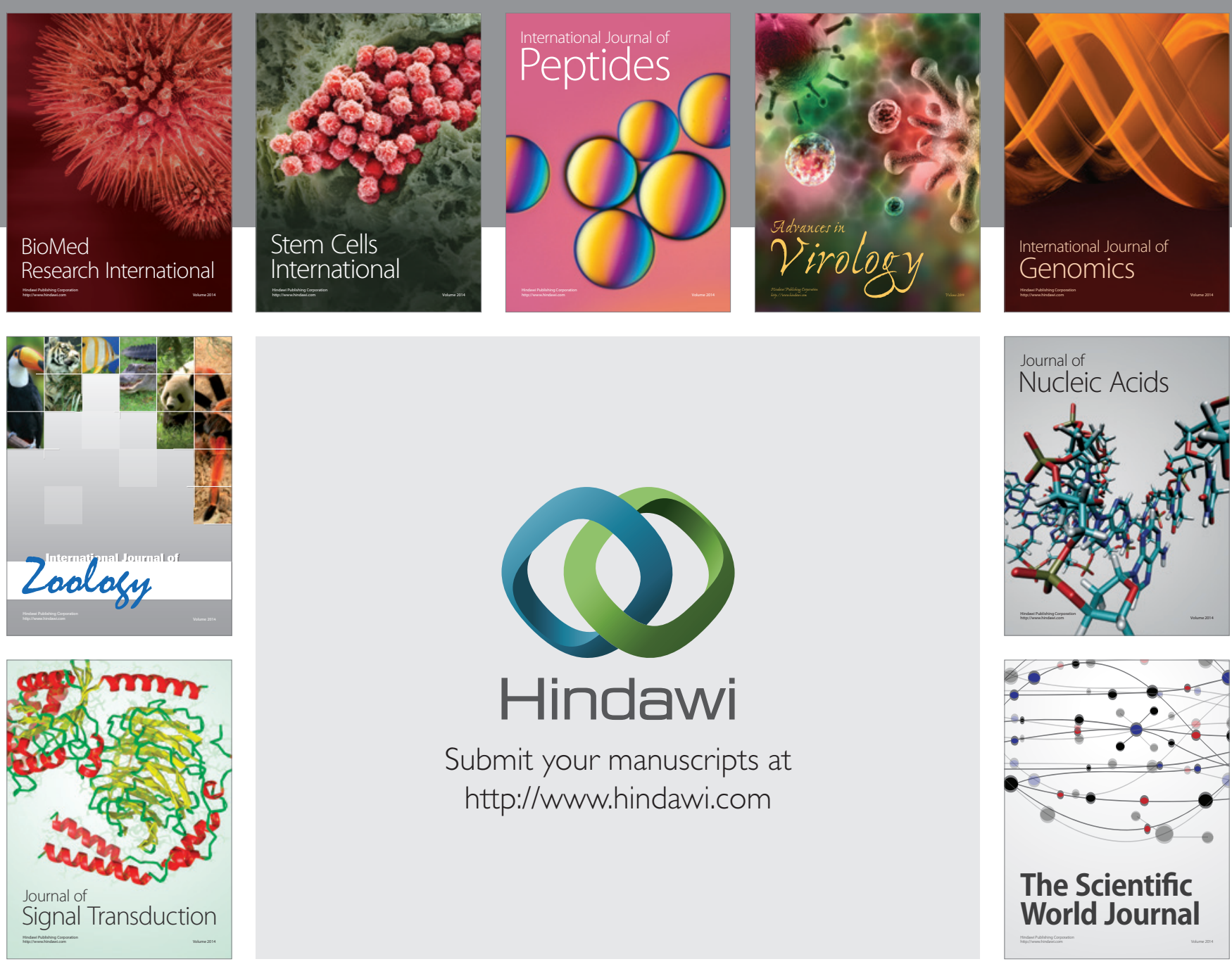

Submit your manuscripts at

http://www.hindawi.com
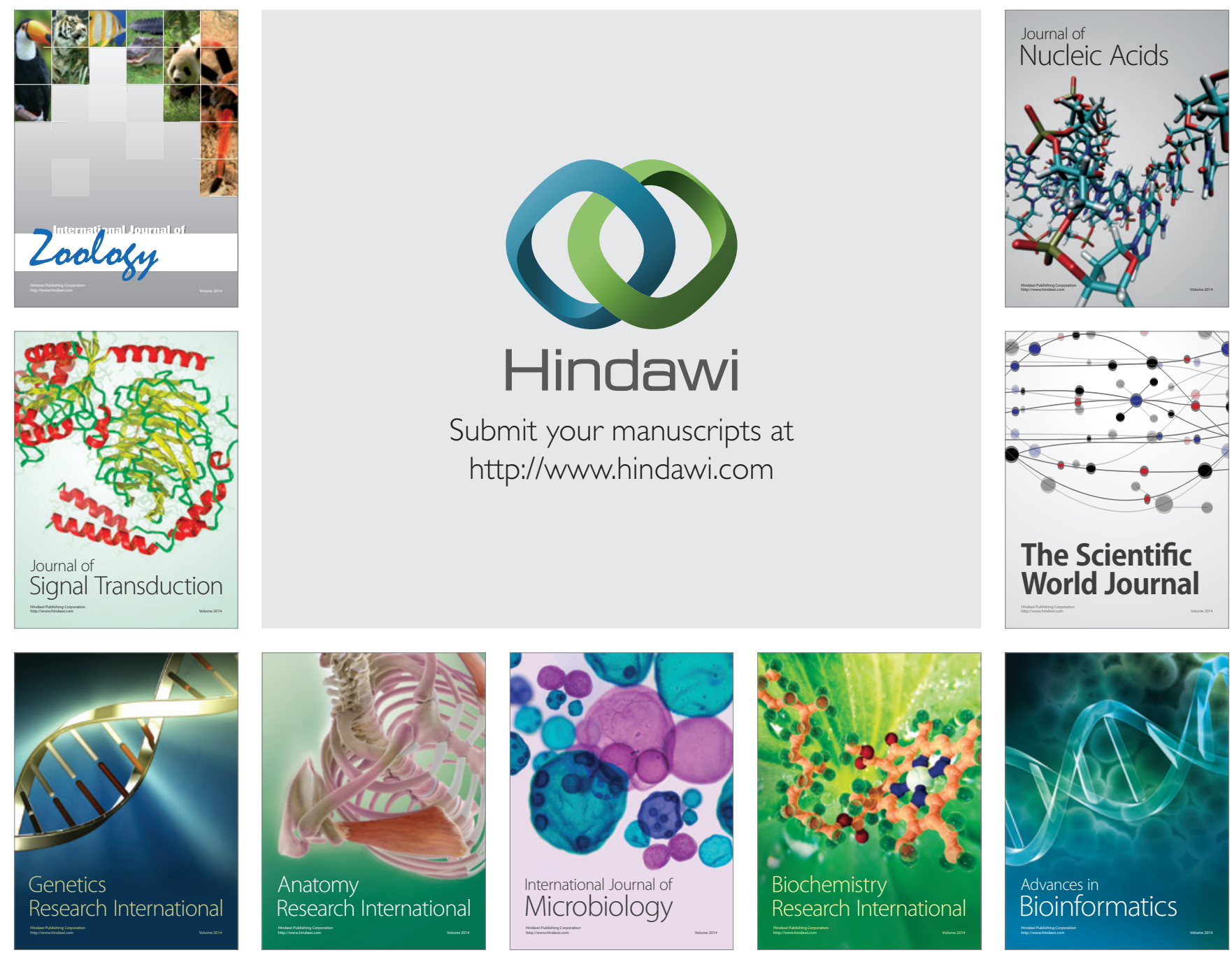

The Scientific World Journal
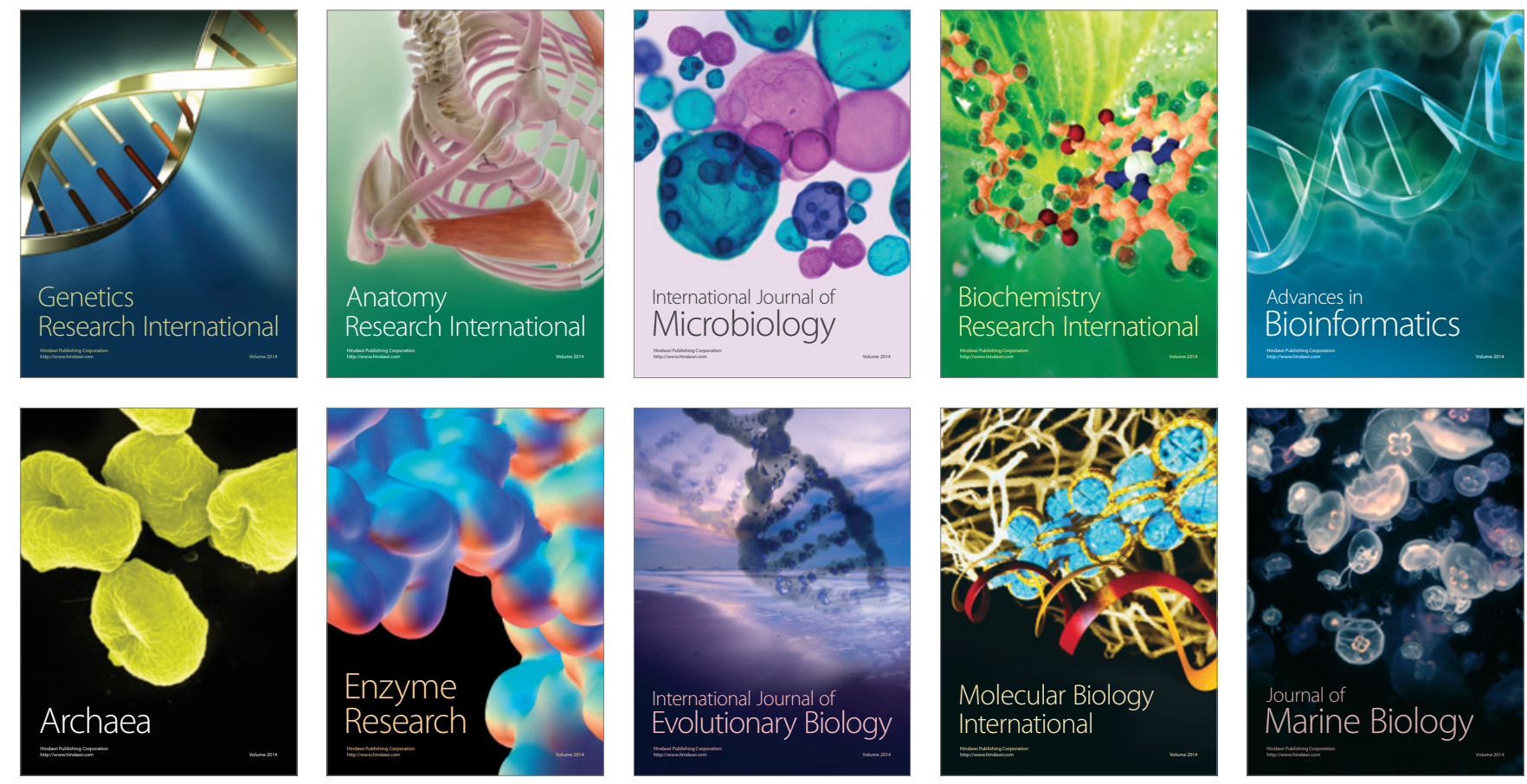